\title{
Temporal variation in the quantitative estimation of total phenolic and flavonoid contents of two species of Calotropis
}

\author{
Arshad Ahmad Najar ${ }^{1}$, Swati Khare², and Kirti Jain ${ }^{3}$ \\ ${ }^{1,3}$ Department of Botany Govt. Science \&t Commerce College Benazir, Bhopal (M.P) India \\ ${ }^{2}$ Department of Botany Govt MLB Girls PG Autonomous College, Bhopal (M.P), India
}

\begin{abstract}
Phenols and flavonoids present in medicinal plants are considered to be among the most important bioactive components. Calotropis procera and Calotropis gigantea are much alike medicinal plants with a wide range of bioactivity. The present study was aimed to evaluate the effect of time on total phenolic content (TPC) and total flavonoid content (TFC) in the methanolic extracts of leaf and flower tissues of C. procera and C. gigantea. TPC and TFC were estimated by spectrophotometric method using gallic acid and quercetin as respective standards. The samples were collected in morning, afternoon and evening session's. Significant variation in TFC and TPC levels was observed in between the selected species. C. procera presented highest TPC in leaves harvested in afternoon $(20.10 \mathrm{mg} / \mathrm{gm})$ and highest TFC in flowers collected in evening $(36.755 \mathrm{mg} / \mathrm{gm})$. In conclusion, the present investigation demonstrates that there is significant effect of harvesting time of different tissues of $C$. procera and $C$. gigantea on their TPC and TFC contents.
\end{abstract}

KEY WORDS: C. GIGANTEA, C. PROCERA, GALLIC ACID, METHANOLIC EXTRACT, QUERCETIN, TFC, AND TPC

\section{INTRODUCTION}

Secondary metabolites are the natural phytochemicals which owe medicinal importance to the plants they belong (Justin et al., 2014). Plant secondary metabolites are a diverse group of molecules that are involved in the adaptation of plants to their environment but are not part of the primary biochemical pathways of cell growth and reproduction (Marinova et al., 2005). They

\section{ARTICLE INFORMATION:}

${ }^{*}$ Corresponding Author:

Received $16^{\text {th }} \mathrm{Feb}, 2016$

Accepted after revision 24 $4^{\text {th }}$ March, 2016

BBRC Print ISSN: 0974-6455

Online ISSN: 2321-4007

3ini: Thomson Reuters ISI SCI Indexed Journal

FAAS Journal Score : 3.48

- A Society of Science and Nature Publication, 2016. All rights reserved.

Online Contents Available at: http//www.bbrc.in/ act in defense purposes to protect a plant from any possible harm in the ecological environment (Stamp et al., 2003). Phenolic compounds are aromatic secondary plant metabolites broadly distributed throughout the plant kingdom (Mamta et al., 2012). They confer unique taste and flavor to the plant and plant derived products (Omas-Barberan and Espin, 2001). Phenolic compounds are one of largest group of secondary metabolites synthesized by plants. They offer great deal of health ben- 
efits to the mankind which include their antioxidant, anti-inflammatory, anti-carcinogenic and other biological properties like reduction in blood cholesterol and lipid levels, delaying the development of chronic diseases such as cancer and Alzheimer's disease (Park et al., (2001), Ali et al., (2011) and Bodeker, (2000). Flavonoids are a class of polyphenols which are water soluble pigments found in the vacuoles of plant cells (Justin et al., 2014). The role of flavonoids in flowers is to act as colouring agents for plant pollinators (Harborne, 1976) and in leaves, these compounds are increasingly believed to promote physiological survival of the plant, protecting it from fungal pathogens and UV-radiation (Harborne, 1993). They are anti-allergic, anti-cancer, antioxidant, anti-inflammatory and anti-viral. (Guardia et al., 2001).

Calotropis gigantea L. (family Asclepiadaceae), commonly known as giant weed or milkweed, is a usual wasteland plant found along degraded roadside and overgrazed pastures (Caius 1986 and Sharma, 1954). Calotropis is drought impermeable and salt tolerant weed growing upto an altitude of $900 \mathrm{~m}$ asl throughout the country (Mueen et al., 2005). It prefers distressed sandy soils with mean annual rainfall: $300-400 \mathrm{~mm}$. It has clusters of waxy flowers that are either white or lavender in colour. $C$. gigantea is a perennial herb with wide pharmacological significance in traditional and Unani systems of medicine. The flowers and bark with milky latex are reportedly known for various biological activities including analgesic, antimicrobial, antioxidant, anti-pyretic, insecticidal, cytotoxic and hepatoprotective activity (Sarkar and Chakravarty, 2014). A wide range of chemical compounds including cardiac glycosides, flavonoids, terpenoids, alkaloids and resins have been isolated from this plant (Singh et al. 2014). Recent studies have shown that, C. asiatica accumulates major phytoconstituents in the months of summer season (Alqahtani et al., 2015). Moreover, studies on Ribes nigrum and 'Zonouz' peel have shown that harvesting time and leaf position have a profound effect on their phenolic contents, (Hallman et al., 2013 and Michael et al., 2015).

Calotropis procera L. (family Asclepiadaceae), commonly known as "Sodom apple" is well known for its high medicinal properties. C. procera is drought-resistant, salt-tolerant, animophilous or antomophilous plant. The plant grows along degraded road sides, lagoon edges and in overgrazed native pastures. It has a preference for and is often dominant in areas of abandoned cultivation, especially sandy soils in areas of low rainfall (Sharma et al., 2011). The leaves are useful in the treatment of paralysis, arthralegia, swelling and intermittent fevers. Methanolic and aqueous extracts of leaves of $C$. procera have been reported to have the potential of antioxidant and antibacterial activity (Patel et al., 2012). The present investigation was aimed to study the effet of collection of two different tissues from two Calotropis species on their TPC and TFC contents. Quantitative measurement shows higher phenolic and flavonoid content in leaf and flower tissues of $C$. procera as compared to that in C. gigantea.

\section{MATERIALS AND METHODS}

Gallic acid and Quercetin $\left(\right.$ MERK $\left.^{\circledR}\right)$, Methanol $\left(\right.$ MERK $\left.^{\circledR}\right)$, Folin-ciocalteu Reagent (MERK) $(1: 10$ in deionised water), Sodium carbonate solution $(7.5 \% \mathrm{w} / \mathrm{v})\left(\right.$ MERK $\left.^{\circ}\right)$, Sodium nitrate (MERK $\left.{ }^{\circledR}\right)$, Alcl3 and $\mathrm{NaOH}\left(\mathrm{MERK}^{\circledR}\right)$. Gallic acid and Quercetin (3 mg) were accurately weighed into a $10 \mathrm{ml}$ volumetric flask, dissolved in small amount of distilled water and the solution was made up to $3 \mathrm{ml}$ with the same solvent to make the final stock of $1 \mathrm{mg} / \mathrm{ml}$.

The aerial parts (leaves and flowers) of the plants were collected in the months of March-April, 2014 from MPCST $23^{\circ} 15^{\prime} 35.760^{\prime \prime} \mathrm{N}$ and $77^{\circ} 24^{\prime} 45.414^{\prime \prime} \mathrm{E}$ and P\&T Colony $23^{\circ} 13^{\prime} 25.582^{\prime \prime} \mathrm{N}$ and77 $23^{\prime}$ 28. 294" E Bhopal, India. The collected plant samples were identified by Dr Zia ul Hasan (Prof and Head, Faculty of Botany, Saifia Science College, Bhopal, India). The specimen samples of $C$. procera and C. gigantea were deposited in the departmental herbarium with respective voucher number 481/Bot/Saifia/2014 and 482/Bot/Saifia/2014.

The plant materials were collected at different intervals of time: (Dawn 6:30 am), (Noon 12:30 am) and (Dusk 6:30 pm) by hand plucking. The samples were washed thoroughly with the distilled water to remove the dirt and other contaminations followed by careful drying under shade at room temperature in order to prevent fungal infection and decomposition of active compounds. The dried leaves and flowers were powdered using a grinder and stored in airtight packing polythenes until required for use.

Extraction was carried out by employing the maceration method. Equal quantities (100 g) of powdered tissues of leaf and flowers were taken and put in 500 $\mathrm{ml}$ plastic container. These samples were macerated with $500 \mathrm{ml}$ of $75 \%$ Methanol. Each was allowed to stand for two weeks with constant shaking at regular intervals under room temperature. After maceration samples were fine filtered through muslin cloth and then by Wattman filter paper and the solvents were evaporated to obtain the methanolic extracts of the leaves and flowers. These served as the stock solutions which were stored in a dry and cool place until needed for analysis.

The amount of total phenolics in the extracts was determined with the Folin- Ciocalteu reagent (Ainsworth and Gillespie, 2007). Gallic acid was used as a standard and the total phenolics were expressed as $\mathrm{mg} / \mathrm{g}$ Gallic acid Equivalents (GAE). For this purpose, the calibration curve of Gallic acid. $1 \mathrm{ml}$ of a standard solution of concentration $0.01,0.02,0.03,0.04$ and $0.05 \mathrm{mg} / \mathrm{ml}$ of 


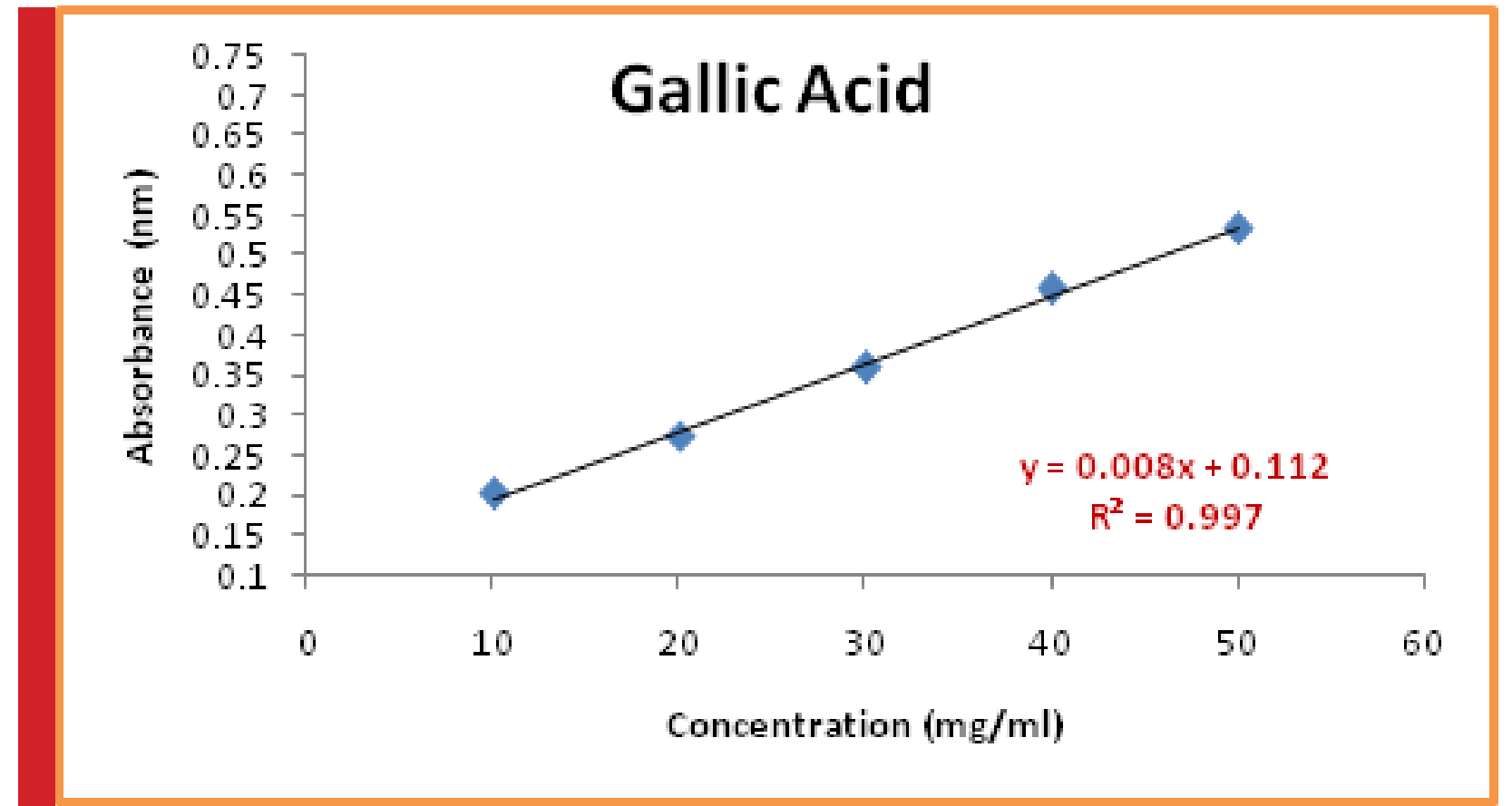

FIGURE 1: Standard Curve of Gallic acid for Total Phenolic content. Line of regression from gallic acid was used for estimation of unknown phenolic content. From the standard curve of gallic acid, line of regression was found to be: $\mathrm{Y}=+0.0085 \mathrm{X}+0.1121$ and $\mathrm{R} 2=0.997$

Gallic acid was prepared in methanol. A concentration of 0.1 or $1 \mathrm{mg} / \mathrm{ml}$ of plant extract was also prepared in methanol and $0.5 \mathrm{ml}$ of each sample were introduced into test tubes and mixed with $2.5 \mathrm{ml}$ of a 10 fold dilute Folin-Ciocalteu reagent and $2 \mathrm{ml}$ of $7.5 \%$ sodium carbonate. The test tubes were allowed to stand for $30 \mathrm{~min}-$ utes at room temperature and the absorbance was read at $760 \mathrm{~nm}$ spectrometrically.

\section{TOTAL FLAVONOID CONTENT}

A double beam UV/Visible spectrophotometric method was used to estimate the flavonoid content (Zhishen et al., 999). A standard solution of quercetin was added to $75 \mu \mathrm{l}$ of $\mathrm{NaNO}_{2}$ solution and mixed for $6 \mathrm{~min}$ before adding $0.15 \mathrm{ml}$ of $\mathrm{Alcl}_{3}(100 \mathrm{~g} / \mathrm{l})$. After $6 \mathrm{~min}, 0.5 \mathrm{ml}$ of $\mathrm{NaOH}$ was added. The final volume was adjusted to 5 $\mathrm{ml}$ with distilled water and thoroughly mixed. Absorbance of the mixture was taken at $510 \mathrm{~nm}$ against water as blank. Total flavonoid content was expressed as mg quercetin/g dry weight of methanolic extract.

\section{RESULTS AND DISCUSSION}

Calotropis $s p$ (Ait.) R. Br., a wild growing plant of family Asclepiadaceae, is well known for its medicinal properties. Different parts of this plant have been reported to exhibit anti-inflammatory, analgesic, and antioxidant properties (Dwivedi et al., 2010). Plant secondary metabolites are a diverse group of molecules that are involved in the adaptation of plants to their environment but are not part of the primary biochemical pathways of cell growth and reproduction. Secondary metabolites from plants have important biological and pharmacological activities, such as anti-oxidative, antiallergic, hypoglycemic and anti-carcinogenic (Borneo and katalinic, 2011). Phenols are a class of secondary metabolites derived from the Shikimic acid pathway. They are believed to function in plant defense mechanisms against insect herbivores and fungi (Nikam et al., 2012).

Flavonoids as secondary metabolites are believed to act in defense related sinalling pathways in the plans against an array of biotic and abiotic stress related conditions (Marinova et al., 2005) . Effect of time of collection (seasonal variation) was evident in the content of TFC and TPC constituents of the two species of Calotropis. The amount of the total phenol was estimated with the Folin-Ciocalteu reagent. Gallic acid was used as a standard compound and the total phenols were expressed as $\mathrm{mg} / \mathrm{g}$ gallic acid equivalent (Fig. 1).

The highest phenolic content (TPC) was found in the methanolic extract $(20.10 \mathrm{mg} / \mathrm{gm})$ of C. the Quercetin reagent. Quercetin was used as a standard compound 


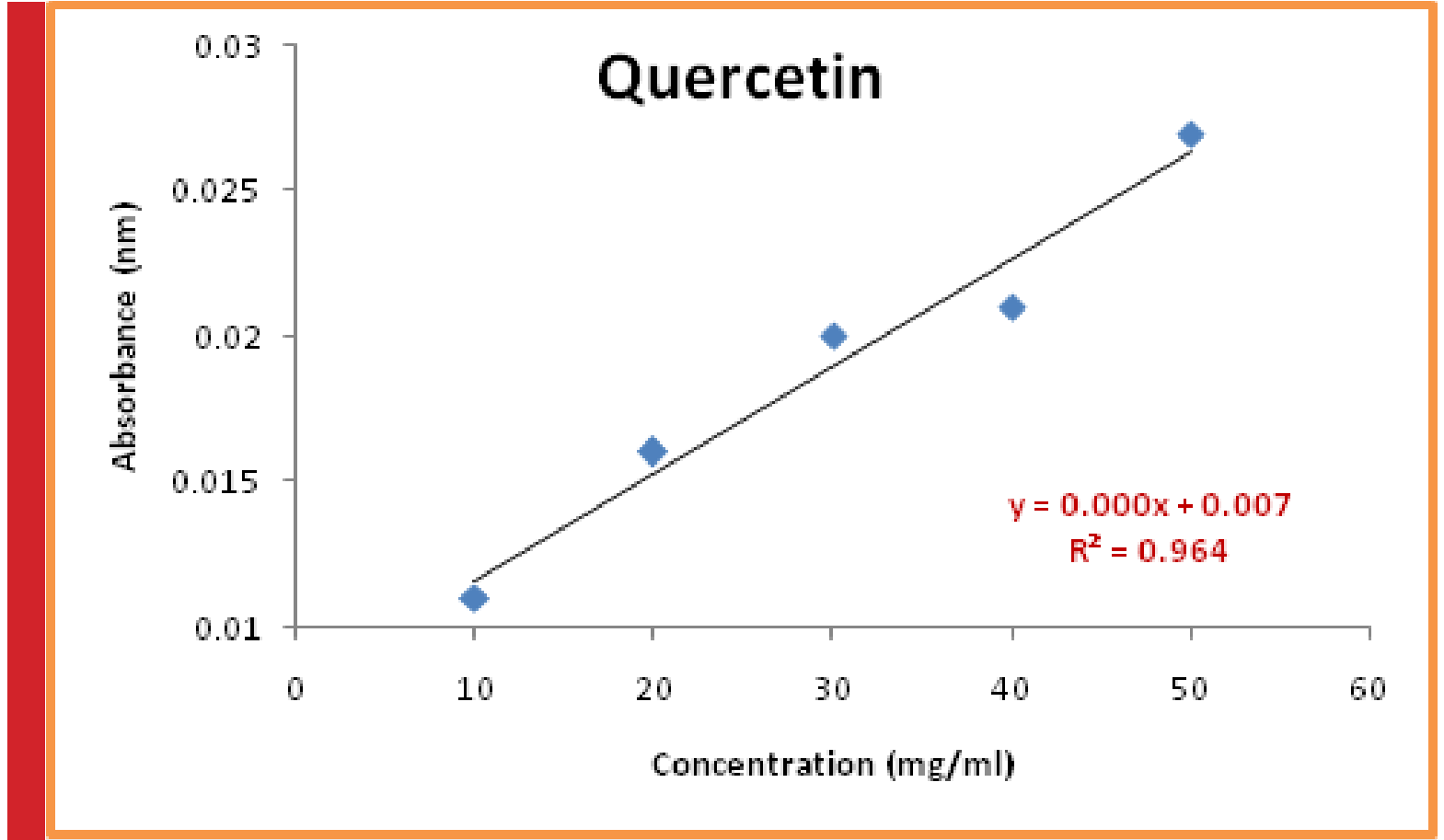

FIGURE 2: Standard Curve of Quercetin for Total Flavonoid content. Line of regression from qurcetin was used for estimation of unknown flavonoid content. From the standard curve of qurcetin, line of regression was found to be: $\mathrm{Y}=0.004 \mathrm{x}+0.0079$ and $\mathrm{R} 2=0.9641$.

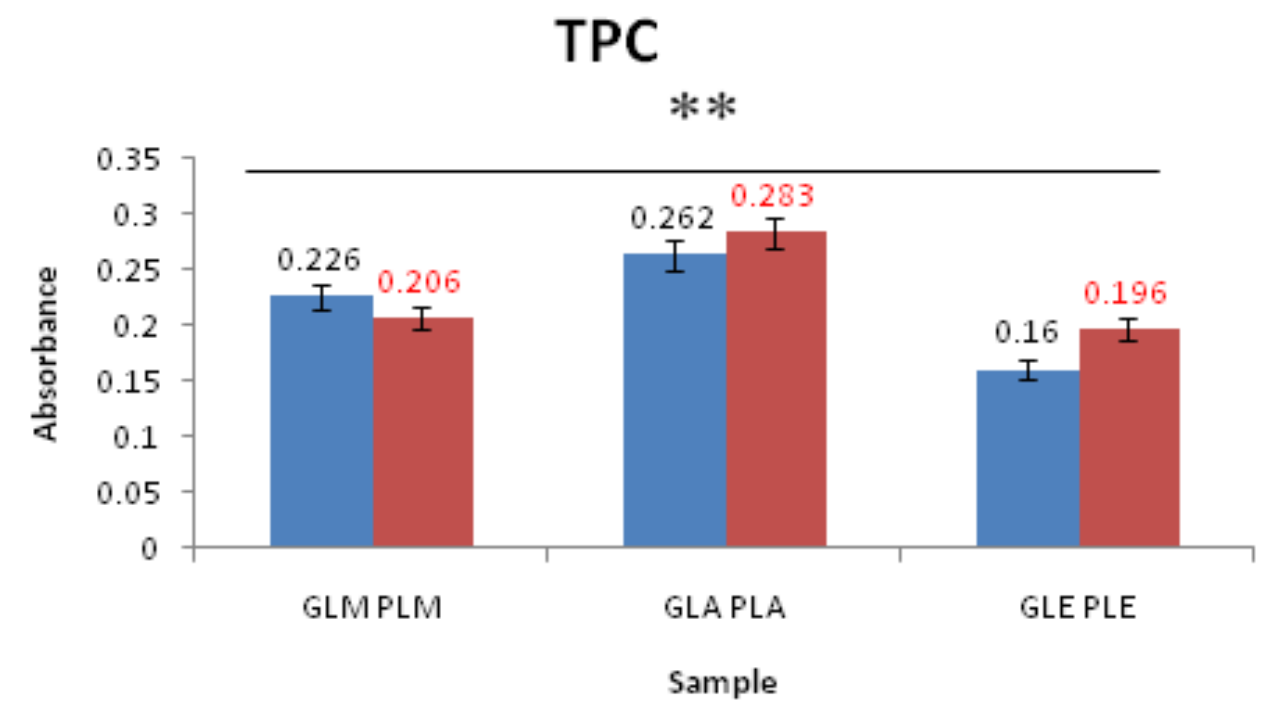

FIGURE 3: TPC Of Calotropis procera leaves and TPC of Calotropis gigantea leaves. Signs: GLM (Gigantea leaves Morning), GLA (Gigantea leaves Afternoon), GLE (Gigantea leaves Evening) PLM (Procera leaves Morning), PLA (Procera leaves Afternoon), PLE (Procera leaves Evening). Data are mean \pm S.D. of three similar experiments. ${ }^{*} \mathrm{P}<0.05 ;{ }^{* *} \mathrm{P}<0.01$. 


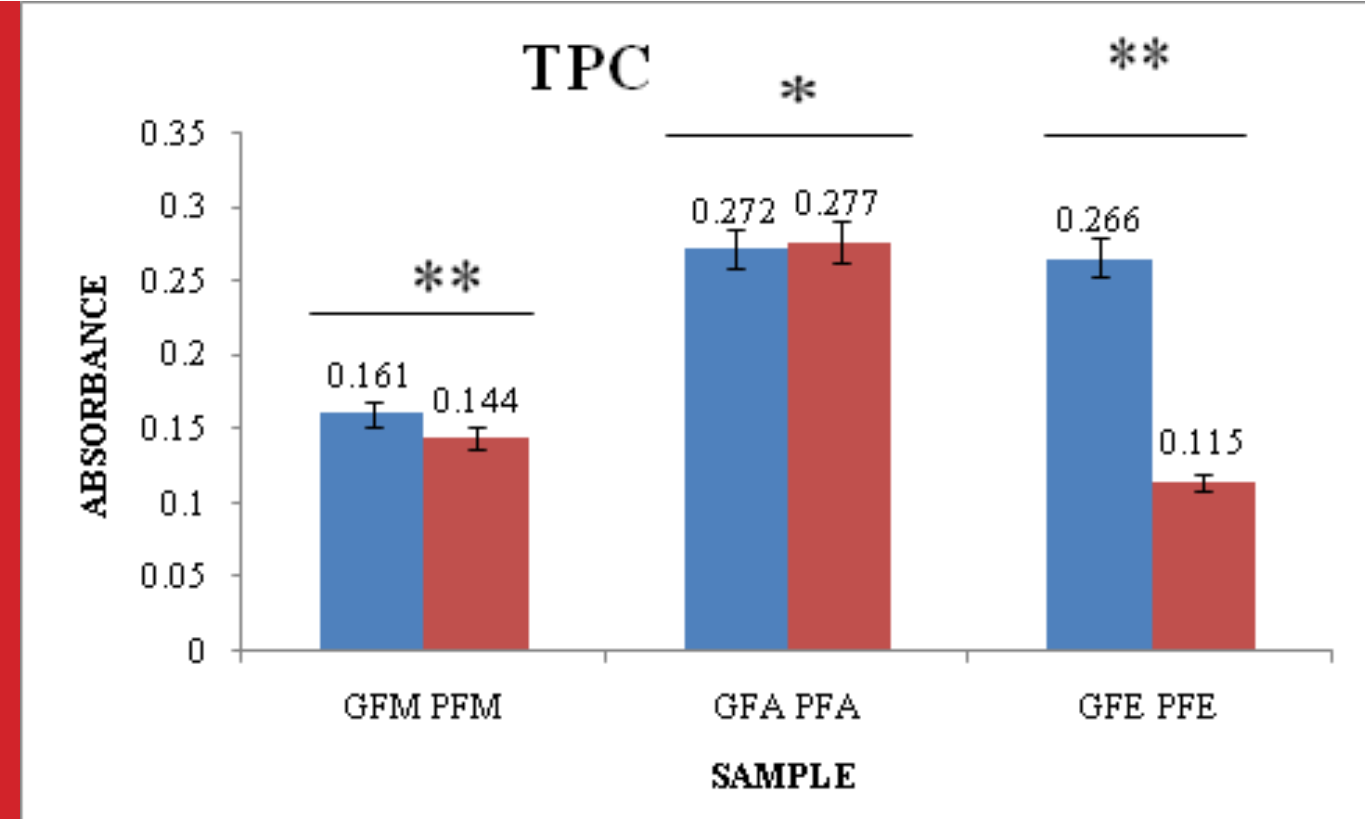

FIGURE 4: TPC Of Calotropis procera flowers and TPC of Calotropis gigantea flowers: Signs: GFM (Gigantea Flowers Morning), GFA (Gigantea Flowers Afternoon), GFE (Gigantea Flowers Evening) PFM (Procera Flowers Morning), PFA (Procera Flowers Afternoon), PFE (Procera Flowers Evening). Data are mean \pm S.D. of three similar experiments. ${ }^{*} \mathrm{P}<0.05 ;{ }^{* *} \mathrm{P}<0.01$.

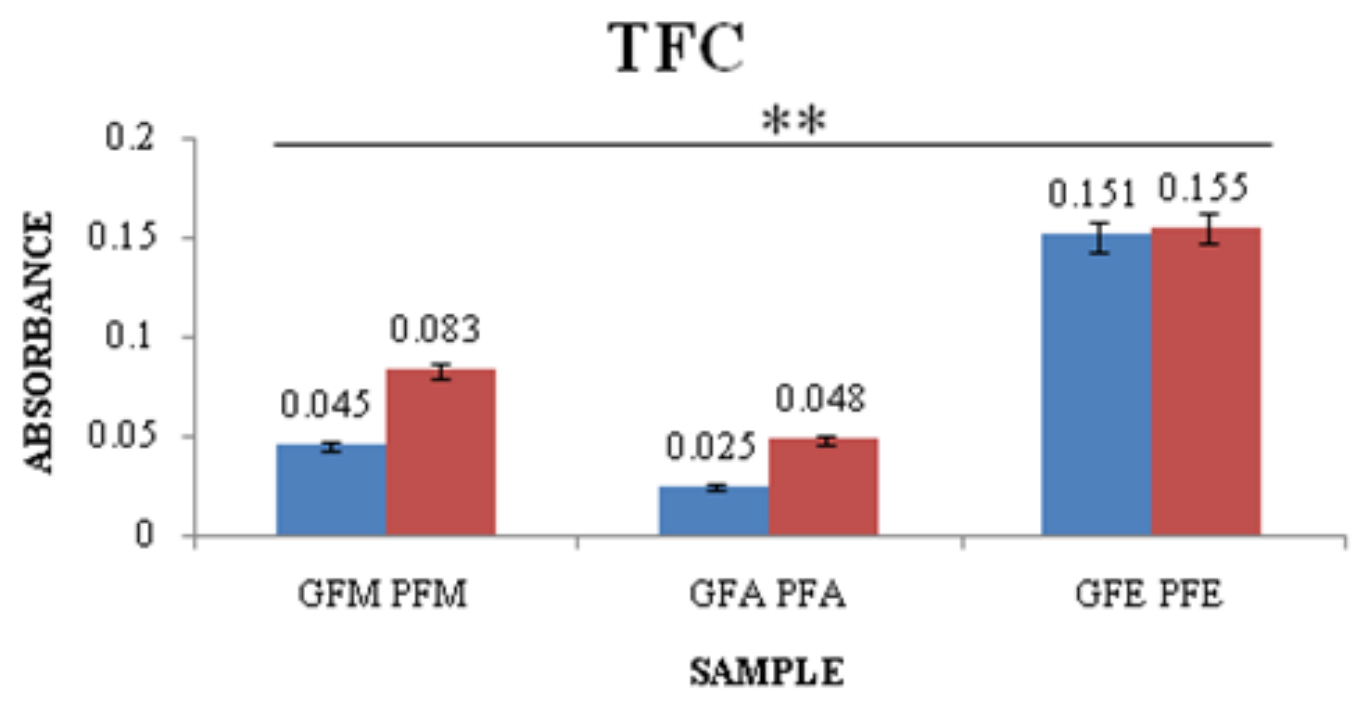

FIGURE 5: TFC Of Calotropis procera flowers and TFC of Calotropis gigantea flowers: Signs: GFM (Gigantea Flowers Morning), GFA (Gigantea Flowers Afternoon), GFE (Gigantea Flowers Evening) PFM (Procera Flowers Morning), PFA (Procera Flowers Afternoon), PFE (Procera Flowers Evening). Data are mean \pm S.D. of three similar experiments. ${ }^{* *} \mathrm{P}<0.01$. 


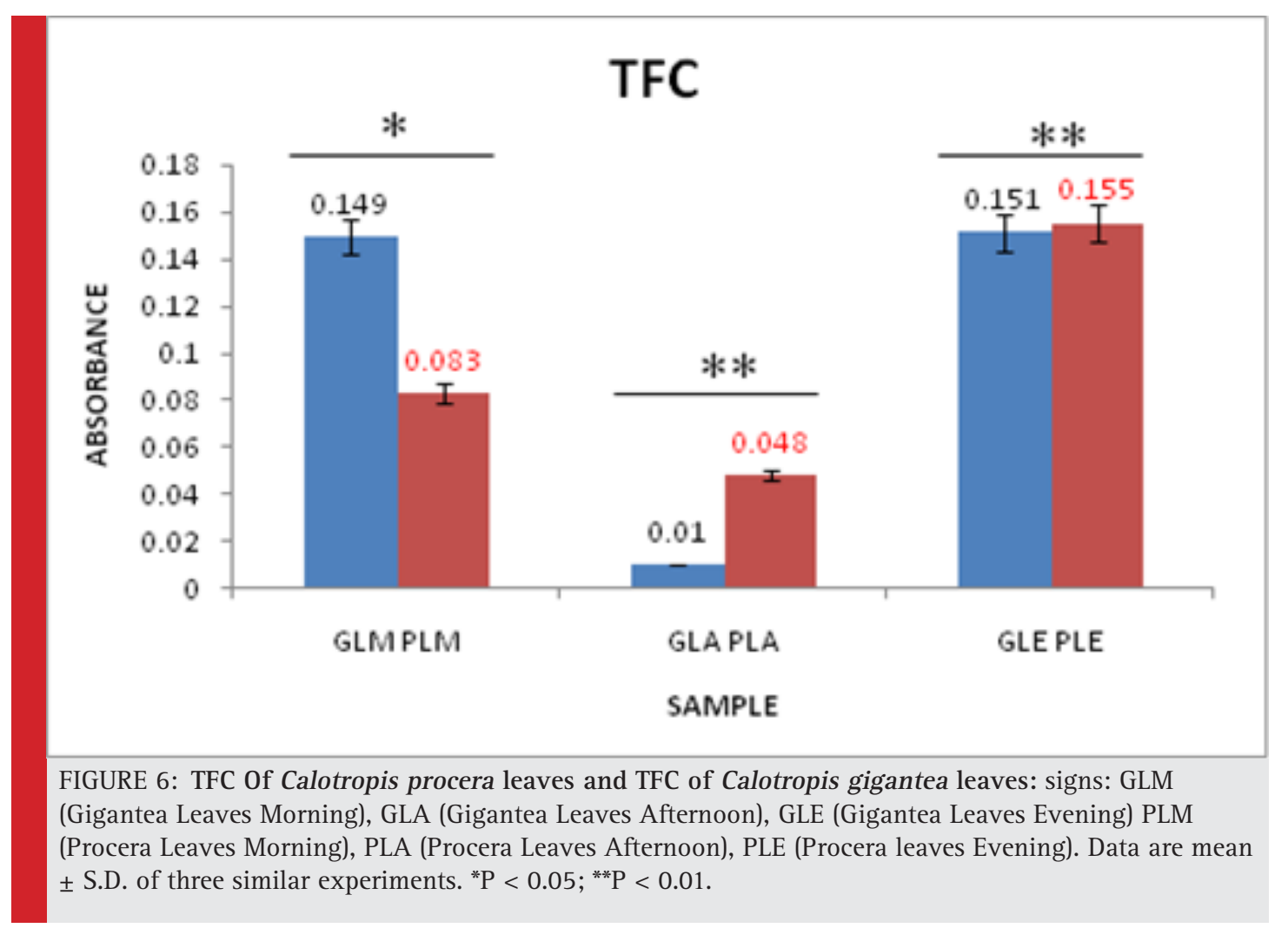

and the Total falvanoids were expressed as $\mathrm{mg} / \mathrm{g}$ Quercetin equivalent (Fig. 2). The highest falvanoid content (TFC) was found in the methanolic extract $(36.755 \mathrm{mg} /$ gm) of C. procera flowers harvested at evening (Fig. 5 and Fig. 6). Our observations were in agreement with earlier such studies on Tecomella $s p$. wherein TPC and TFC where found to be higher in summer season than in winter or monsoon seasons (Patel and Patel, 2014).

Similar studies have been reported on C. asiatica wherein it was shown to accumulate major phytoconstituents in the months of summer season (Alqahtani et al., 2015). Moreover, studies on Ribes nigrum and 'Zonouz' peel have shown that harvesting time and leaf position have a profound effect on their phenolic contents and (Michael et al., 2015 and Hallman et al., 2013). The place of cultivation and the harvesting period affects the phenolic compounds in fruit tissues of two C. asiatica cultivars (Puttarak and Panchayupakaranant, 2012).

Here we have observed that time of collection has profound prospect in ascertaining the drug quality and further selection of elite chemovariant among the two species of Calotropis. However, the present study needs further investigation as to how the chemical composition of different tissues is affected by period of harvesting.

\section{CONCLUSION}

The present study revealed that time of collection has special effects on total phenolic content (TPC) and total flavonoid content (TFC) of C. gigantea and C. procera. Quantitative measurement shows higher phenol and flavonoid content in leaf and flower tissues of Calotropis procera in afternoon and evening sessions compared to Calotropis gigantea. Such studies have a prospect in deciding on proper timing of collection visavis selection of elite chemotype and further exploration for drug design and development.

\section{REFERENCES}

Ainsworth E.A, and Gillespie E.M. (2007). Estimation of Total phenolic content and other oxidation substrates in plant tissue using Folin-Ciocalteu reagent. Nature protocol. 2(4):875-877.

Ali G, and Neda G. (2011). Flavonoids and phenolic acids: Role and biochemical activity in plants and human. Journal of Medicinal Plants Research. 5(31): 6697-6703.

Alqahtani A, Tongkao-On W, Li KM, Razmovski-Naumovski V, Chan K, Li GQ. (2015). Seasonal Variation of Triterpenes and Phenolic Compounds in Australian Centella asiatica (L.) Urb. Phytochem Analysis. 26(6):436-43.

Bodeker G.( 2000). Traditional health system: valuing biodiversity for human health and well being. Cultural and Spiritual Values in Biodiversity. 24: 261-284. 
Borneo and katalinic (2011). Total phenolic content, flavonoid concentration and antioxidant activity of marrubium peregrinuml. extracts Kragujevac. Journal Sci. 33: 63-72.

Caius JF. (1986). The medicinal and poisonous plants of India, Scientific publications, Jodhpur. Calotropis R. Br., in The wealth of India - A Dictionary Indian Raw materials, Revised series, (1992) Publication and information Directorate, CSIR, New Delhi. 3:78-84.

Dwivedi A, Chaturvedi M, Gupta A, Argal A. (2010). Medicinal utility of Calotropis procera (Ait.) R. Br. as used by natives of village Sanwer of Indore District, Madhya Pradesh. International Journal of Pharmacy \&t Life Sciences. 1(3): 188-190.

Guardia T, Rotelli AE, Juarez A0, Pelzer LE. (2001). Antiinflammatory Properties of Plant Flavonoids. Effects of Rutin, Quercetin and Hesperidin on Adjuvant Arthritis in Rat. Farmaco. 56 (9): 683-7.

Hallman E, Lipowski J , Marszalek K, and Rembialkowska E. (2013).The Seasonal Variation in Bioactive Compounds Content in Juice from Organic and Non-organic Tomatoes. Plant Foods Hum Nutr. 68(2): 171-176 .

Harborne JB. (1993). The flavonoids: advances in research since 1986. London UK Chapman and Hall. 134: 543-553.

Harborne JB. (1976). Functions of Flavonoids in Plants, In Chemistry and Biochemistry of Plant Pigments. TW Goodwin Academic press New York. 67: 736-778.

Justin NK, Semana E, Ally RM, Xin H. (2014). Plant Secondary Metabolites: Biosynthesis, Classification, Function and Pharmacological Properties. Journal of Pharmacy and Pharmacology. 2: 377-392.

Justin NK, Edmond S, Ally R, Mussa, Xin H. (2014). Plant Secondary Metabolites: Biosynthesis, Classification, Function and Pharmacological Properties. Journal of Pharmacy and Pharmacology. 2: 377-392.

Mamta S, Jyoti S and Dr Alka P.(2012). Flavonoids and phenolic acids as antioxidants in plants and human health. Int. J. Pharm. Sci. Rev. Res.16(2):130-134.

Marinova D, Ribarova F, Atanassova M. (2005). Total phenolics and Total flavonoids in Bulgarian fruits and vegetables. Journal of the university of chemical technology and metallurgy. 40 (3):255-260.

Marinova D, Ribarova F, Atanassova M. (2005). Total phenolics and total flavonoids in bulgarian fruits and vegetables. Journal of the University of Chemical Technology and Metallurgy. 40 (3) 255-260.
Michael V, Sean C, Derek S, Staffan C. Andersson, Susan V, Eva J, Kimmo R.. (2015). Phenolic compounds in blackcurrant (Ribes nigrum L.) leaves relative to leaf position and harvest date. Food Chemistry. (172):35-14

Mueen AK, Rana AC, Dixit VK. (2005). Calotropis species (Ascelpediacea) - A comprehensive review. Pharmacognosy magazine. 1(2): 48-52.3.

Nikam P.H, Kareparamban J, Jadhav A, Kadam V. (2012). Future Trends in Standardization of Herbal Drugs. Journal of Applied Pharmaceutical Science .02 (06): 38-44.

Omas-BF, and Espin JC. (2001). Phenolic compounds and related enzymes as determinants of quality of fruits and vegetables. Jour Sci Food Agric. 81:853-876.

Park ES, Moon WS, Song MJ, Kim MN, Chung KH, Yoon JS. (2001). Antimicrobial Activity of Phenol and Benzoic Acid Derivatives. International biodeterioration and biodegradation. 47 (4): 209-14.

Patel A. K and Patel I. C. (2014). Seasonal effects on some Phytochemicals accumulation of Tecomella undulata (SM.) Seem. International journal of pharmaceuticals and Biologicals. 4 (I).

Patel HV, Patel JD, Patel B. (2012). Comparative efficacy of Phytochemical analysis and Antioxidant activity of Methanolic extract of Calotropis gigantea and Calotropis procera. International Journal of Biological \&t Pharmaceutical Research.5(2): 107-113.

Puttarak P, Panchayupakaranant P. (2012). Factors affecting the content of pentacyclic triterpenes in Centella asiatica raw materials. Pharmaceutical Biology : 50.

Sarkar S, and chakraverty RA. (2014). Calotropis Gigantea Linn. - A Complete Busket Of Indian Traditional Medicine.Int. J. Pharm. Res. Sci. 02(1): 7-17.

Sharma AK, Kharb R, Kaur R. (2011). Pharmacognostical Aspects of Calotropis procera (ait.) R. Br. International Journal of Pharma and Bio Sciences. 2(1).

Sharma GK. (1934). Calotropis procera and Calotropis gigantea, Indian journal of veterinary science. 4:63-74.

Singh N, Gupta P, Patel A .V, Pathak A. K. (2014). Calotropis gigantea: A review on its Phytochemical \& Pharmacological Profile. International Journal Parmocology. 1(1): 1-8.

Stamp N. (2003). Out of the Quagmire of Plant Defense Hypotheses. The Quarterly Review of Biology. 78 (1):23-55.

Zhishen J, Mengcheng T, Jianming W. (1999). The determination of flavonoid contents in mulberry and their scavanging effects on superoxide radicals. Food Chem. 64:555-559. 